Original Research Paper

\title{
Difference Long Irradiation on The Growth Rate of Kappaphycus Alvarezii
}

\author{
Lulu Lutfiati $^{1}$, Nunik Cokrowati ${ }^{1 *}$, Fariq Azhar ${ }^{1}$ \\ ${ }^{1}$ Program Studi Budidaya Perairan' Fakultas Pertanian, Universitas Mataram, Mataram,
}

\author{
Article History \\ Received : December 05 ${ }^{\text {th }}, 2021$ \\ Revised : December $15^{\text {th }}, 2021$ \\ Accepted : December $25^{\text {th }}, 2021$ \\ Published : January $05^{\text {th }}, 2022$ \\ *Corresponding Author: \\ Nunik Cokrowati, \\ Program Studi Budidaya Perairan \\ Universitas Mataram, Indonesia \\ Email: \\ nunikcokrowati@unram.ac.id
}

\begin{abstract}
The study aimed to find out the long-standing difference in irradiation to the growth rate of Kappaphycus alvarezii in controlled containers. The method used is experimental. This study used a Complete Randomized Design (RAL) using four (4) treatments with 3 repeats, namely the treatment of P1 control (without irradiation), P2 (8 hours of irradiation), P3 (10-hour irradiation), P4 (12-hour irradiation). The data were analyzed using analysis of variance (ANOVA) at a rate of $5 \%$ with a confidence interval of $95 \%$ and continued with the Duncan test. In this study, the average results of absolute weight and the highest specific daily growth rate at $\mathrm{P} 4$ treatment of $25.67 \pm 1.53 \mathrm{gr}, 3.30 \pm 0.06 \%$, followed by P3 treatment $21 \pm 2 \mathrm{gr}$, $3.11 \pm 0.09 \%$, P2 treatment $16 \pm 1$ gr, $2.87 \pm 0.06 \%$, and lowest P1 treatment $12.33 \pm 2.08 \mathrm{gr}, 2.63 \pm 0.15 \%$. The average value of light intensity in each treatment is P1 1053 \pm 41.00 lux, P2 1256 \pm 27.71 lux, P3 1479 \pm 0.58 lux, and P4 1668 \pm 34.64 lux. Water quality parameters during maintenance are in the normal limit range for seaweed maintenance. D treatment produces the highest growth value this is because the light is an energy source in the process of photosynthesis, in chlorophyll plants, photosynthesis is the main process determining the rate of growth. The quality and amount of light that enters affects the growth of seaweed. This research concluded that the maintenance of Kappaphycus alvarezii in controlled containers with different irradiation had a significant effect on growth. 12 hours irradiation (P4) gave the best growth with an absolute weight of $16.00 \mathrm{~g}$, and a specific growth rate of $4.06 \%$ per day and gave the highest chlorophyll-a value of $2.72 \mathrm{mg} / \mathrm{l}$. Meanwhile, the highest phycoerythrin value was found in (P1) without irradiation, which was $4.58 \mathrm{mg} / \mathrm{l}$.
\end{abstract}

Keywords: Aquaculture, chlorophyll, Kappaphycus alvarezii, Light, Seaweed.

\section{Pendahuluan}

Rumput laut yang mempunyai nilai ekonomis penting adalah Kappaphycus alvarezii (Azizah et al., 2018). Penggunaan rumput laut jenis ini semakin meningkat tidak untuk industri makanan saja tetapi juga sebagai bahan baku produk kecantikan, obat-obatan, dan bahan baku untuk kegiatan industri lainnya. Rumput laut dari jenis Kappaphycus alvarezii dapat menghasilkan hidrokolid karagenan yang penting secara komersial (Isa et al., 2016; Naseri et al., 2020). Karagenan mempunyai kemampuan untuk membentuk gel. Karagenan dapat dimanfaatkan dalam berbagai bidang usaha seperti usaha dalam bidang industri pangan dan non-pangan, farmasi maupun kosmetik.

Karagenan dalam industri pangan memiliki fungsi yang penting diantaranya sebagai pengental. Karagenan digunakan dalam banyak produk susu, keju, yogurt, permen, es krim, dan produk coklat. Menurut Rasyid (2003) mengatakan bawa penggunaan karagenan dalam industri makanan tergantung pada beberapa sifat kelarutan, viskosotas dan kekuatan gel. Dalam bioteknologi, karagenan sering digunakan sebagai gel untuk melumpuhkan sel/enzim. Sedangkan dalam pengobatan eksprerimental, karagenan digunakan untuk pengujian obat antiinflamasi. Giyatmi et al., (2020) karaginan dapat digunakan sebagai bahan baku obat. 
Tingginya permintaan pasar terhadap rumput laut jenis Kappaphycus alvarezii ini sehingga mengharuskan para pembudidaya dan para pengusaha harus selalu menyediakan stok rumput laut jenis Kappaphycus alvarezii ini secara terus menerus. Budidaya Kappaphycus alvarezii masih banyak menghadapi kendala apabila dibudidayakan di habitat aslinya seperti cuaca buruk serta terserangnya hama dan penyakit, tetapi apabila dibudidayakan pada wadah terkontrol kendala-kendala tersebut akan sedikit mudah diatasi karena Kappaphycus alvarezii dibudidayakan pada wadah terkontrol. Cokrowati et al., (2021) menjelaskan gagal panen dapat disebabkan cuaca ekstrim yaitu terjadinya angin kencang, arus kuat dan gelombang tinggi.

Prastowo et al., (2019) plantet rumput laut hasil kultur jaringan, tumbuh optimal pada media dengan penyinaran selama 9 jam. Darmawati (2013) menjelaskan bahwa pertumbuhan optimal Kappaphycus alvarezii yang dibudidayakan di laut pada kedalaman $50 \mathrm{~cm}$ dari permukaan air laut, menghasilkan pertumbuhan optimal. Hal tersebut terkait dengan perolehan cahaya matahari yang digunakan untuk fotosintesis. Rukisah et al., (2020) pertumbuhan optimal Kappaphycus alvarezii dipengaruhi intensitas cahaya, kecerahan perairan dan padatan tersuspensi dalam perairan. Oleh karena itu, dilakukannya penelitian ini bertujuan untuk mengetahui perbedaan lama penyinaran terhadap laju pertumbuhan Kappaphycus alvarezii pada wadah terkontrol sehingga nantinya diharapkan mendapatkan hasil produksi yang maksimal.

\section{Bahan dan Metode}

Metode penelitian yang digunakan adalah metode eksperimen. Penelitian ini dilaksanakan dari 29 November 2020 sampai dengan 31 Maret 2021, di Laboratorium Budidaya Program Studi Budidaya Perairan, Fakultas Pertanian, Universitas Mataram. Selanjutnya, Uji kandungan klorofil- $a$ dan fikoeritrin dilakukan di Laboratorium Kimia Analitik Fakultas Matematika dan Ilmu Pengetahuan Alam (MIPA), Universitas Mataram. Alat yang digunakan adalah alat tulis, aerasi, bak kontainer, handphone, $\mathrm{pH}$ meter, Disolved Oxigen (DO) meter, refraktometer, log book, lampu LED 40 watt, kabel, kepala lampu, gunting, saringan, galon, turbidimeter, timbangan digital, lux meter. Bahan yang digunakan adalah air laut, bibit Kappaphycus alvarezii, aquades, sampel air laut, aseton $10 \mathrm{ml}$, bufer fosfat $0,1 \mathrm{M} 10 \mathrm{ml}$, test kit nitrat, test kit fosfat, tali rafia, lakban.

Sementara itu, penelitian menggunakan rancangan acak lengkap (RAL) yang terdiri atas 4 perlakuan serta masing-masing perlakuan dilakukan 3 kali ulangan sehingga diperoleh 12 unit percobaan. perlakuan P1 tanpa penyinaran lampu, perlakuan $\mathrm{P} 2$ penyinaran selama 8 jam, perlakuan P3 penyinaran 10 jam, perlakuan P4 penyinaran 12 jam.

Parameter yang diukur adalah sebagai berikut :

\section{Berat Mutlak}

Pertumbuhan mutlak dihitung menggunakan rumus (Basir et al., 2017) sebagai berikut :

$$
\mathrm{Ga}=\frac{\mathrm{M} 2-\mathrm{M} 1}{\mathrm{t} 2-\mathrm{t} 1}
$$

Keterangan :

$\mathrm{Ga}=$ Laju Pertumbuhan Mutlak

M1 = Berat rumput laut pengukuran pertama

M2 = Berat rumput laut pengukuran kedua

$\mathrm{t} 1=$ Durasi penimbangan ke-1

t2 = Durasi penimbangan ke-2

\section{Laju Pertumbuhan Spesifik}

Pertumbuhan spesifik dapat dihitung dengan rumus menurut Dawes, (1994) :

$$
\mathrm{SGR}=\frac{\mathrm{Ln} \mathrm{Wt}-\mathrm{Ln} \mathrm{W} 0}{\mathrm{t}} \times 100 \%
$$

Keterangan :

SGR = Laju Pertumbuhan Spesifik (\%)

$\mathrm{Wt}=$ Bobot rerata individu pada akhir kegiatan $(\mathrm{g})$

W0 = Bobot rerata individu pada awal kegiatan $(\mathrm{g})$

$\mathrm{t} \quad=$ Waktu kegiatan (hari)

\section{Kandungan Klorofil- $a$}

Kandungan klorofil- $a$ dianalisis melalui ekstrasi $10 \mathrm{~g}$ talus dicincang dengan pasir kuarsa hingga halus, kemudian ditambahkan $10 \mathrm{ml}$ aseton $90-100 \%$. Wadah selanjutnya dibungkus dengan alumunium foil dan didinginkan selama semalam. Kemudian disentrifugasi 1.400 kali selama 2 menit. Selanjutnya klorofil- $a$ diukur menggunakan spektrofotometer. 


\section{Kandungan Fikoeritrin}

Kandungan fikoeritrin dianalisis melalui ekstrasi $10 \mathrm{~g}$ talus dicincang dengan pasir kuarsa hingga halus, kemudian ditambahkan $10 \mathrm{ml} \mathrm{0,1}$ $\mathrm{M}$ buffer fosfat dan $\mathrm{pH} 6.8$ selama semalam. Selanjutnya disentrifugasi 1000 kali selama 2 menit dan diukur menggunakan spektrofotometer.

\section{Pengukuran Intensitas Cahaya}

Pengukuran intensitas cahaya dilakukan satu kali selama penelitian. Dilakukan pengukuran intesnitas cahaya dengan menggunakan Lux Meter. Lux meter dinyalakan dengan menekan tombol power. Kemudian pilih range, selanjutnya sensor cahaya diarahkan ke daerah yang akan diukur dan lihat hasil pengukuran pada layar panel.

\section{Kualitas Air}

Parameter kualitas air yang diamati antara lain suhu, oksigen terlarut, $\mathrm{pH}$, Salinitas, nitrat, fosfat.

Analisis data

Data penelitian dianalisis menggunakan Analysis of Variance (ANOVA) dan diuji lanjut Duncan dengan taraf kepercayaan 95\%. Variabel yang dianalisis dengan anova adalah berat mutlak, laju pertumbuhan spesifik, klorofil-a, dan fikoeritrin.

\section{Hasil dan Pembahasan}

\section{Berat Mutlak}

Pertumbuhan berat mutlak Kappaphycus alvarezii yang diamati dari awal penanaman hingga akhir pemanenan selama 30 hari masa pemeliharaan dalam penelitian dapat dilihat di bawah ini:

\section{Berat Mutlak}

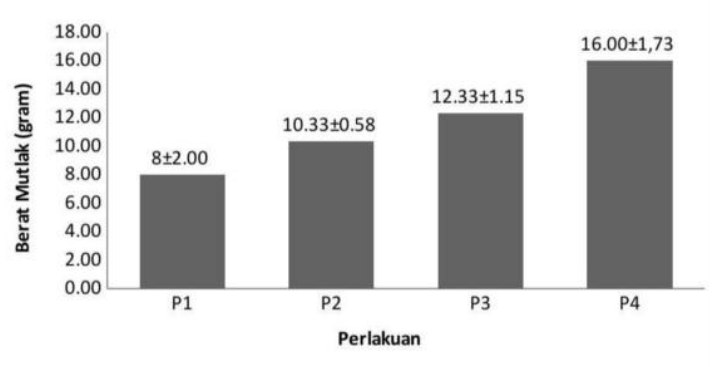

Gambar 1. Berat mutlak Kappaphycus alvarezii.
Keterangan : $\mathrm{P} 1=$ tanpa penyinaran $; \mathrm{P} 2=$ penyinaran 8 jam; $\mathrm{P} 3=$ penyinaran $10 \mathrm{jam} ; \mathrm{P} 4=$ penyinaran $12 \mathrm{jam}$.

Dari grafik, menunjukkan bahwa perbedaan lama penyinaran memberikan pengaruh pada berat mutlak. Berat mutlak Kappaphycus alvarezii paling tinggi terdapat pada perlakuan P4 (penyinaran 12 jam) dengan 16,00 gram, diikuti perlakuan P3 (penyinaran 10 jam) dengan 12,33 gram, kemudian diikuti oleh perlakuan P2 (penyinaran 8 jam) 10,33 gram, dan terrendah didapatkan pada perlakuan P1 (tanpa penyinaran) sebesar 8 gram. Dari hasil grafik di atas terlihat perbedaan berat mutlak pada setiap perlakuan.

Pertumbuhan rumput laut dipengaruhi oleh intensitas sinar matahari yang diterima (Cokrowati et al., 2020). Perbedaan intensitas sinar matahari atau cahaya yang diterima rumput laut akan mempengaruhi proses pertumbuhannya, karena banyak sedikitnya intensitas sinar matahari atau cahaya yang diterima oleh rumput dapat mempengaruhi tingkat pertumbuhan. Hasil penelitian perbedaan lama penyinaran memiliki efek nyata pada berat mutlak Kappaphycus alvarezii. Nilai pada grafik menunjukkan bahwa perlakuan P4 dengan penyinaran 12 jam merupakan respons terbaik terhadap pertumbuhan Kappaphycus alvarezii selama penelitian. Perbedaan pertumbuhan disebabkan oleh lamanya pencahayaan yang diberikan. Pencahayaan dapat digunakan untuk proses fotosintesis, dimana semakin lama pencahayaan diberikan maka proses fotosintesis berlangsung secara optimal dan akan menghasilkan nilai pertumbuhan yang tinggi. Oleh karena itu, ini menunjukkan bahwa paparan yang lama memiliki pengaruh baik pada pertumbuhan kappaphycus alvarezii.

Faktor pembatas yang dapat mempengaruhi pertumbuhan rumput laut adalah penetrasi sinar. Hubungan antara pengaruh cahaya dengan pertumbuhan tanaman dikendalikan oleh sistem pigmen yang dikenal sebagai fitokrom yang terdiri dari kromofor dan protein, dimana kromofor ini merupakan bagian peka terhadap sinar matahari. Cahaya berpengaruh pada proses fotosintesis karena cahaya dapat memicu aktivitas pembelahan sel, sehingga terjadi pelebaran dan ekstensi (perpanjangan) pada bagan tubuh atau thalus 
rumput laut yang pada akhirnya rumput laut akan mengalami pertumbuhan. (Akib et al., 2015).

\section{Laju Pertumbuhan Spesifik}

Kappaphycus alvarezii dari penanaman awal penelitian hingga minggu terakhir 30 hari pemeliharaan dapat dilihat pada grafik di bawah ini:

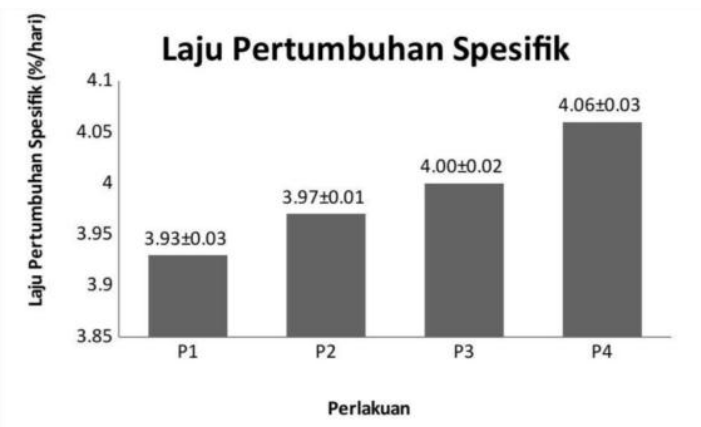

Gambar 2. Laju pertumbuhan spesifik

Keterangan : $\mathrm{P} 1=$ tanpa penyinaran; $\mathrm{P} 2=$ penyinaran 8 jam; $\mathrm{P} 3=$ penyinaran $10 \mathrm{jam} ; \mathrm{P} 4=$ penyinaran $12 \mathrm{jam}$.

Nilai pertumbuhan spesifik paling tinggi terdapat pada perlakuan P4 (penyinaran 12 jam) dengan nilai 4,06 \%/hari, kemudian diikuti perlakuan P3 (penyinaran 10 jam) sebesar 4,00 \%/hari, selanjutnya P2 (penyinaran 8 jam) 3,97 $\% /$ hari, dan yang paling rendah didapatkan pada perlakuan P1 (tanpa penyinaran) 3,93\%/hari. Perbedaan lama penyinaran memberikan efek nyata terhadap laju pertumbuhan spesifik Kappaphycus alvarezii. Penyinaran 12 jam mempunyai pertumbuhan lebih bagus dibandingkan perlakuan yang lain, karena diduga intensitas cahaya tercukupi dalam pertumbuhannya serta lamanya penyinaran pada perlakuan tersebut. Dengan demikian, perbedaan lama penyinaran memberikan pengaruh nyata pada pertumbuhan spesifik Kappaphycus alvarezii.

Organisme autotorof memanfaatkan cahaya yang berasal dari matahari untuk mengubahnya menjadi energi melalui aktifitas klorofil. Pada penelitian ini cahaya lampu atau penyinaran lampu yang diberikan dapat digunakan Kappaphycus alvarezii untuk fotosintesis karena tingkat pertumbuhan rumput laut sebagai tanaman berklorofil ditentukan oleh fotosintesis sebagai proses utamanya. Rumput laut akan tumbuh dan berkembang secara normal ketika proses fotosintesis yang dibantu sinar matahari bekerja dengan maksimal (Dewi \& Ekawaty, 2018). Kemudian semakin lama penyinaran cahaya pada rumput laut dapat memberikan nilai pertumbuhan yang lebih tinggi, oleh karena itu intensitas cahaya yang bagus dapat memberikan pertumbuhan yang maksimal (Burdames et al., 2014).

Terjadi peningkatan pertumbuhan dari semua perlakuan yang digunakan pada setiap minggunya, hal ini menandakan bahwa perbedaan penyinaran cahaya tersebut memberikan pengaruh terhadap pertumbuhan Kappaphycus alvarezii. Nilai pada grafik menunjukkan bahwa perlakuan P4 dengan penyinaran selama 12 jam merupakan respon terbaik terhadap pertumbuhan Kappaphycus alvarezii. Perbedaan laju pertumbuhan spesifik disebabkan oleh lamanya pencahayaan yang diterima. Pencahayaan ini digunakan pada proses fotosintesis, dimana semakin lama penyinaran maka fotosintesis akan berlangsung optimal sehingga menghasilkan pertumbuhan yang maksimal. Oleh karena itu, hal ini berarti bahwa pertumbuhan Kappaphycus alvarezii dipengaruhi oleh lama pencahayaan yang diberikan.

\section{Kandungan Fikoeritrin}

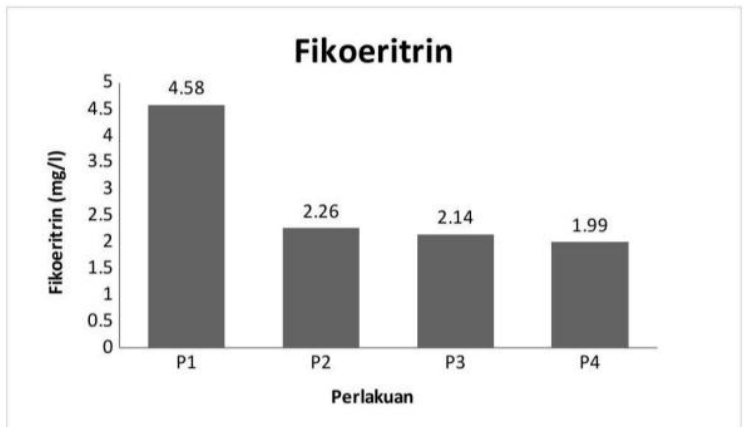

Gambar 3. Kandungan fikoeritrin

Keterangan : $\mathrm{P} 1=$ tanpa penyinaran; $\mathrm{P} 2=$ penyinaran 8 jam; $\mathrm{P} 3=$ penyinaran 10 jam; $\mathrm{P} 4=$ penyinaran 12 jam.

Nilai tertinggi terdapat pada perlakuan tanpa penyinaran (P1) yaitu $4,58 \mathrm{mg} / \mathrm{l}$, urutan kedua diikuti oleh perlakuan penyinaran selama 8 jam (P2) yaitu 2,26 mg/l, kemudian oleh perlakuan penyinaran 10 jam (P3) yaitu 2,14 $\mathrm{mg} / \mathrm{l}$. Kandungan fikoeritrin terendah terdapat di 
perlakuan 12 jam penyinaran (P4) yaitu 1,99 $\mathrm{mg} / \mathrm{l}$. Secara umum tidak hanya klorofil dan karetanoid saja yang digunakan dalam proses fotosintesis tetapi terdapat juga pigmen pelengkap yang disebut fikoeritrin, dimana fikoeritrin ini dibutuhkan rumput laut guna membantu menangkap cahaya melalui klorofil pada saat fotosintesis (Basir et al., 2017). Kandungan fikoeritrin pada Kappaphycus alvarezii menyebabkan warna sedikit kemerahan pada thallus. Selain itu, fikoeritrin ini membantu klorofil- $a$ menyerap cahaya pada saat berlangsungnya proses fotosintesis.

Perlakuan tanpa penyinaran pada penelitian ini memberikan nilai fikoeritrin yang tinggi. Tingginya kandungan fikoeritrin disebabkan oleh dinding sel rumput laut yang kurang menerima cahaya. Menurut Cokrowati et al., (2020) yang menyatakan bahwa kurangnya cahaya atau sinar matahari yang diserap rumput laut menyebabkan pembentukan fikoeritrin lebih tinggi, hal ini merupakan bentuk adaptasi secara otomatis dilakukan rumput laut ketika cahaya yang diserap tidak optimal, pada bagian thallus yang menerima sedikit atau tidak ada sinar matahari diduga terjadi pembentukan fikoeritrin lebih sebagai bentuk adaptasi thallus rumput laut dalam kondisi yang tidak mendapatkan sinar matahari yang optimal. Kemudian Afandi et al., (2018) juga mengatakan kandungan fikoeritrin yang tinggi di Kappaphycus alvarezii disebabkan oleh kurangnya pencahayaan. Oleh karena itu perlakuan tanpa penyinaran memberikan nilai kandungan fikoertrin yang tinggi.

Menurut Subagio \& Kasim, (2019) pembentukan fikoeritrin merupakan upaya yang dilakukan rumput laut untuk menanggapi kondisi dimana terjadinya kesulitan untuk menghasilkan klorofil-a. Sementara itu penyinaran 12 jam (P4) memiliki kandungan fikoeritrin yang rendah dibandingkan penyinaran selama 8 jam (P2) dan penyinaran 10 jam (P3). Hal ini diduga karena pada penyinaran 12 jam (P4) kandungan klorofil$a$ lebih banyak digunakan dalam penyerapan cahaya untuk fotosintesis.

\section{Klorofil- $a$}

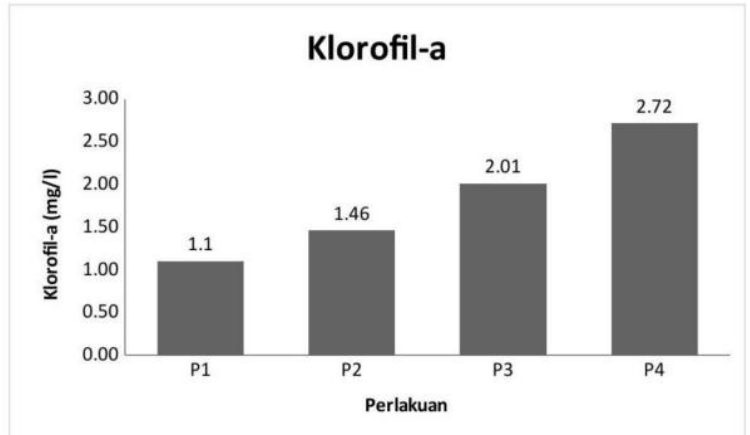

Gambar 4. Kandungan klorofil- $a$

Keterangan : $\mathrm{P} 1=$ tanpa penyinaran, $\mathrm{P} 2=$ penyinaran 8 jam, $\mathrm{P} 3=$ penyinaran 10 jam, $\mathrm{P} 4=$ penyinaran $12 \mathrm{jam}$.

Penyinaran selama 12 jam (P4) menghasilkan klorofil- $a$ tertinggi yaitu 2,72 $\mathrm{mg} / \mathrm{l}$. Kandungan klorofil- $a$ urutan kedua adalah perlakuan penyinaran selama $10 \mathrm{jam}$ (P3) yaitu 2,01 mg/l, kemudian diikuti oleh perlakuan penyinaran selama 8 jam (P2) sebesar 1,46 mg/l. Klorofil- $a$ terendah terdapat pada perlakuan tanpa penyinaran (P1) yaitu $1,10 \mathrm{mg} / \mathrm{l}$.

Pertumbuhan rumput laut dipengaruhi oleh zat hijau daun yang biasa disebut klorofil. M(Mahardika et al., 2018) pada ganggang laut hanya klorofil a, b, dan c yang diisolasi, sedangkan klorofil terdiri dalam bentuk a, b, c, d, dan e. Klorofil a, b, dan c hanya pada kelompok tertentu, tetapi klorofil- $a$ ditemukan disemua jenis alga. Sebagian besar ganggang di laut mempunyai klorofil- $a$ dan pada proses fotosintesis klorofil- $a$ memiliki peran yang penting. Jumlah klorofil $\mathrm{b}$ dan $\mathrm{c}$ pada tumbuhan lebih sedikit jika dibandingkan dengan klorofila. Sehingga pada proses pertumbuhan Kappaphycus alvarezii klorofil- $a$ lebih berpengaruh dan dibutuhkan karena merupakan zat hijau daun yang bekerja sebagai pengubah serta penyerap energi untuk pertumbuhan (Aulia et al., 2019).

Ketersediaan unsur hara yang sesuai serta kualitas air yang baik pada media pemeliharaan membuat rumput laut tumbuh optimal. Menurut Cokrowati et al., (2020) selain teknik budidaya dan kondisi kualitas air yang baik terdapat juga klorofil- $a$ yang mempengaruhi serta mendukung terjadinya pengembangan rumput laut dalam kegiatan akuakultur. Pertumbuhan rumput laut akan meningkat ketika proses fotosintesis berlangsung optimal, dimana untuk mengoptimalkan proses fotosintesis maka 
dibutuhkan penyerapan cahaya oleh klorofil- $a$ sesuai dengan kebutuhan. Oleh karena itu, rumput laut membutuhkan klorofil- $a$ untuk mempertahankan hidupnya serta bersaing dengan organisme lain pada habitat tertentu. Hasil penelitian ini menunjukkan bahwa penyinaran 12 jam (P4) dalam budidaya Kappaphycus alvarezii memiliki kadar klorofil- $a$ paling tinggi. Perlakuan tersebut dapat memberi ruang bagi semua bagian Kappaphycus alvarezii agar dapat menyerap cahaya yang cukup sesuai kebutuhan, dimana untuk melakukan proses fotosintesis rumput laut membutuhkan cahaya yang digunakan berasal dari lampu. Sementara itu peningkatan kemampuan rumput laut untuk mendapatkan nutrisi bersumber dari meningkatnya proses fotosintesis yang berlangsung.

Faktor pembatas yang dapat mempengaruhi pertumbuhan Kappaphycus alvarezii adalah penetrasi cahaya, dimana energi yang dihasilkan dari hasil fotosintesis tidak akan seimbang ketika cahaya yang diterima kurang dari tingkat kebutuhan. Sedangkan rumput laut akan mengalami kematian apabila cahaya yang diterima berlangsung secara berkala (Mahardika et al., 2018). Oleh karena itu, menurut Yuan (2007) dengan adanya klorofil rumput laut dapat terlindungi dari radiasi UV berlebih dan jaringan tumbuan terhindar dari stres oksidatif.

Pada perlakuan penyinaran 8 jam (P2) dan 10 jam (P3) memberikan nilai klorofil- $a$ yang rendah daripada perlakuan 12 jam $(\mathrm{P} 4)$, hal ini diduga karena kurangnya penetrasi cahaya yang diterima. Ketika Kappaphycus alvarezii mengalami peningkatan pertumbuhan sebagian besar thallus saling menutupi sehingga menghalangi penetrasi cahaya ke dinding sel rumput laut. Pernyataan ini diperkuat oleh Cokrowati et al., (2020) yang menjelaskan ketika rumput laut Kappaphycus alvarezii semakin besar, beberapa thallus akan saling menutupi sehingga membentuk keteduhan yang akhirnya menghalangi penetrasi cahaya ke dinding sel.

\section{Kualitas Air}

Pertumbuhan Kappaphycus alvarezii yang dibudidaya dipengaruhi oleh faktor eksternal seperti kualitas air. Hasil pengamatan kualitas air selama 4 minggu pemeliharaan menunjukan bahwa nilai kisaran suhu, $\mathrm{pH}$, DO, salinitas, kekeruhan, nitrat, dan fosfat masih dalam batas kelayakan budidaya Kappaphycus alvarezii. Hasil pengamatan kualitas air dalam dilihat dalam di bawah ini.

Kualitas Air
\begin{tabular}{|c|c|c|c|c|}
\hline Parameter & P1 & P2 & P 3 & P 4 \\
\hline Suhu $\left({ }^{\circ} \mathbf{C}\right)$ & $27.0-27.8$ & $27.1-28.3$ & $27.1-28.0$ & $27.3-27.9$ \\
\hline DO (mg/) & $7.4-8.7$ & $7.3-9.0$ & $7.4-9.0$ & $7.3-9.0$ \\
\hline pH & $6.8-8.1$ & $6.9-8.1$ & $6.8-8.2$ & $6.8-8.2$ \\
\hline Salinitas (ppt) & 31 & 31 & $31-34$ & $30-34$ \\
\hline $\begin{array}{c}\text { Kekeruhan } \\
\text { (NTU) }\end{array}$ & $0.51-2.72$ & $0.59-3.71$ & $0.53-2.28$ & $0.55-1.99$ \\
\hline Nitrat (mg/) & 0,8 & 0,8 & 0,8 & 0,8 \\
\hline Fosfat (mg/) & 0.03 & 0.03 & 0,03 & 0,03 \\
\hline
\end{tabular}

Gambar 5. Kualitas Air

Keterangan : $\mathrm{P} 1=$ tanpa penyinaran, $\mathrm{P} 2=$ penyinaran 8 jam, $\mathrm{P} 3=$ penyinaran 10 jam, $\mathrm{P} 4=$ penyinaran 12 jam.

Pengukuran kualitas air merupakan hal yang penting dalam keberlangsungan penelitian Kappaphycus alvarezii. Selain beradaptasi terhadap cahaya, pertumbuhan Kappaphycus alvarezii juga dipengaruhi oleh kualitas air media pemeliharaan misalnya suhu. Suhu ini dapat mempengaruhi proses fisiologis rumput laut yaitu proses fotosintesis, respirasi, dan metabolisme. Menurut Kordi (2010) yang mengatakan bahwa rumput laut Eucheuma sp. cocok pada suhu air yang berkisar antara $20^{\circ} \mathrm{C}$ $30^{\circ} \mathrm{C}$. Berdasarkan hasil penelitian menunjukkan bahwa pada media pemeliharaan Kappaphycus alvarezii memiliki suhu yang berkisar antara $27.0^{\circ} \mathrm{C}-28.3^{\circ} \mathrm{C}$, dimana ini adalah kadar suhu yang optimal bagi Kappaphycus alvarezii. BSN (2011) menjelaskan bahwa suhu $26^{\circ} \mathrm{C}-32^{\circ} \mathrm{C}$ merupakan standar optimum untuk pemeliharaan rumput laut. Dan menurut (Yulius, 2017) suhu $25^{\circ} \mathrm{C}-31^{\circ} \mathrm{C}$ adalah suhu yang optimum untuk budidaya Kappaphycus alvarezii. Oleh karena itu, hal ini menunjukkan bahwa kondisi suhu pada media pemeliharaan selama penelitian sesuai untuk pertumbuhan Kappaphycus alvarezi.

Pertumbuhan rumput laut di lingkungan budidaya dapat dipengaruhi oleh salinitas yang terkait dengan tekanan osmotik antara rumput laut dan lingkungan perairan. Salinitas dapat mempengaruhi pertumbuhan rumput laut, dan setiap organisme memiliki toleransi yang berbeda. Selama penelitian kisaran salinitas berada pada angka 30-34 ppt, dimana kondisi salinitas ini merupakan standar optimum yang dapat mendukung pertumbuhan Kappaphycus 
alvarezii. Menurut BSN (2011) yang menjelaskan bahwa pertumbuhan rumput laut akan maksimal ketika salinitas berkisar antara 28-34 mg/l. Oleh karena itu, hal ini menunjukkan bahwa salinitas pada media pemeliharaan selama penelitian sesuai untuk pertumbuhan Kappaphycus alvarezii. $\mathrm{pH}$ mempengaruhi pertumbuhan dan aktivitas biologi rumput laut. Proses metabolisme dan respirasi akan terganggu ketika kadar $\mathrm{pH}$ dalam air mengalami perubahan, dimana kondisi ini dapat membahayakan kelangsungan hidup rumput laut. Selama penelitian diperoleh kadar $\mathrm{pH}$ sebesar 6,8-8,2 pada media budidaya. Kondisi $\mathrm{pH}$ ini merupakan $\mathrm{pH}$ yang dapat mendukung pertumbuhan Kappaphycus alvarezii. Menurut BSN (2011) kondisi $\mathrm{pH}$ yang optimum untuk pertumbuhan rumput laut yaitu 7-8,5. Yulius (2017) juga menjelaskan bahwa setiap spesies memiliki batas toleransi terhadap perubahan $\mathrm{pH}$ dimana $\mathrm{pH} 7$ 8,5 merupakan kisaran yang baik bagi kehidupan organism laut, jika berada di luar kisaran itu akan mengganggu pertumbuhannya. Oleh karena itu, kondisi $\mathrm{pH}$ pada media pemeliharaan ini cocok untuk pertumbuhan Kappaphycus alvarezii.

Dalam menjalani hidupnya rumput laut membutuhkan oksigen terlarut sebagai kebutuhan dasar. Hasil pengukuran oksigen terlarut pada media pemeliharaan Kappaphycus alvarezii diperoleh kisaran 7,4-,9,0 mg/l. Kisaran tersebut dapat mendukung pertumbuhan Kappaphycus alvarezii. Menurut BSN (2011) rumput laut akan tumbuh dengan sempurna pada perairan dengan oksigen terlarut $>4 \mathrm{mg} / \mathrm{l}$. Dan menurut Astriana et al., (2019) menjelaskan bahwa rumput laut membutuhkan oksigen terlarut sebesar 2-4 ppm atau lebih untuk pertumbuhan.

Tumbuhan tingkat tinggi membutuhkan fosfat dalam pertumbuhannya. Unsur ini merupakan faktor pembatas untuk tanaman air serta ganggang. Fosfat juga mempengaruhi tingkat kesuburan perairan. Hasil pengukuran fosfat pada media pemeliharaan Kappaphycus alvarezii diperoleh kisaran $0,03 \mathrm{mg} / \mathrm{l}$. Kondisi fosfat ini masih dapat ditoleransi oleh Kappaphycus alvarezii, dimana menurut BSN (2011) pertumbuhan rumput laut akan maksimal pada perairan yang kandungan fosfatnya sebesar $>0,1 \mathrm{mg} / \mathrm{l}$. Kadar fosfor yang baik dalam air untuk produktivitas Kappaphycus alvarezii adalah $0,02-1,0 \mathrm{mg} / \mathrm{l}$.
Nitrat dalam air diperlukan untuk menunjang pertumbuhan rumput laut seperti produksi, pembentukan karbohidrat, protein, lemak dan menghasilkan cadangan makanan dalam bentuk senyawa organik. Hasil pengukuran nitrat pada media pemeliharaan Kappaphycus alvarezii diperoleh kisaran 0,8 $\mathrm{mg} / \mathrm{l}$. Kondisi nitrat ini merupakan kondisi nitrat yang dapat mendukung pertumbuhan Kappaphycus alvarezii. Menurut BSN (2011) yang menyatakan bahwa kandungan nitrat $>0,04$ $\mathrm{mg} / \mathrm{l}$ merupakan standar optimal untuk pertumbuhan rumput laut. Yulius (2017) juga menjelaskan bahwa kandungan nitrat dibutuhkan setiap alga dengan kadar yang berbeda, dan kandungan nitrat cukup bagi Kappaphycus alvarezii yaitu 0,9-3,5 mg /l.

Pertumbuhan rumput laut dipengaruhi oleh kekeruhan air pada media budidaya. Laju fotosintesis akan menurun ketika terjadi peningkatan kekeruhan, dimana hal ini disebabkan oleh kurangnya penetrasi cahaya yang masuk ke dalam air karena pada dasarnya budidaya rumput laut membutuhkan perairan dengan tingkat kekeruhan yang rendah atau perairan yang jernih dan terhindar dari pengaruh sedimentasi serta intrusi air dari sungai. Hasil pengukuran kekeruhan pada media pemeliharaan Kappaphycus alvarezii diperoleh kisaran 0,51 NTU sampai 3,71 NTU. Menurut Majid et al., (2016) menyatakan bahwa kondisi kekeruhan optimum bagi rumput laut adalah kurang dari 20 NTU. Sedangkan berdasarkan BSN (2011) menjelaskan bahwa baku mutu optimal kekeruhan untuk rumput laut adalah < 40 NTU.

Berdasarkan penelitian yang telah dilakukan semua perlakuan mengalami peningkatan pertumbuhan, hanya saja penyinaran 12 jam (P4) yang tingkat pertumbuhannya paling baik. Ini menunjukkan bahwa Kappaphycus alvarezii memberikan peningkatan panjang dan massa. Pertumbuhan ini dikendalikan oleh faktor lingkungan yang berada pada laboratorium seperti $\mathrm{pH}$, suhu, salinitas, DO, nitrat, fosfat dan kekeruhan serta intensitas cahaya. Dalam proses fotosintesis memerlukan cahaya, dimana fotosintesis ini merupakan faktor utama untuk pertumbuhan rumput laut Kappaphycus alvarezii. Kappaphycus alvarezii sebagai tanaman berklorofil, sehingga fotosintesis adalah proses utama yang menentukan tingkat pertumbuhan. 
Rumput laut akan tumbuh dan berkembang secara normal ketika proses konversi zat organic oleh sinar matahari (fotosintesis) berlangsung secara optimal (Runtuboy \& Abadi, 2018).

\section{Pencahayaan}

Proses fotosintesis pada Kappaphycus alvarezii membutuhkan sinar matahari atau cahaya, karena rumput laut jenis ini cuma bisa tumbuh pada kedalaman yang masih terjangkau oleh matahari. Cahaya mempunyai peran penting dalam fotosintesis. Energi cahaya yang diserap tanaman sangat bergantung terhadap intensitas cahaya dan lama penyinaran sinar. Hasil pengukuran intensitas cahaya pada penelitian ini didapatkan bahwa semua perlakuan memiliki nilai intensitas cahaya yang berbeda. Pencahayaan yang diperoleh dalam penelitian ini adalah pencahayaan yang baik bagi pertumbuhan rumput laut karena hasil pengukuran pencahayaan selama penelitian berkisar antara 1006 Lux-1351 Lux. Menurut Aulia et al., (2019) menjelaskan bahwa tanaman menerima cahaya dengan batas optimal sebesar 1750 Lux.

Pada proses fotosintesis membutuhkan cahaya, dimana untuk mendapatkan pertumbuhan rumput laut yang optimal maka dibutuhkan pencahayaan yang cukup. Ketika penerimaan cahaya berada di bawah tingkat kebutuhan rumput laut maka akan mempengaruhi proses fotosintesis. Pada penelitian ini cahaya yang digunakan berasal dari lampu putih. Berdasarkan penelitian yang telah dilakukan penggunaan lampu putih dapat memberikan pertumbuhan yang optimal pada rumput laut, dimana menurut Aulia et al., (2019) lampu putih sesuai sebagai pengganti cahaya matahari karena menghasilkan intensitas sinar yang baik untuk semua tanaman. Cahaya yang digunakan pada penelitian ini berasal dari lampu dengan watt 40 . Penggunaan lampu 40 watt dengan intensitas cahaya sebesar 1059 Lux dapat memberikan hasil pertumbuhan yang optimal. Alhadi (2016) menjelaskan bahwa penggunaan lampu berwarna putih dengan watt 40 hampir sama dengan cahaya yang dihasilkan oleh matahari.

\section{Kesimpulan}

Berdasarkan hasil analisis data penelitian diperoleh bahwa pemeliharaan Kappaphycus alvarezii dalam wadah terkontrol dengan penyinaran yang berbeda memiliki efek nyata pada pertumbuhan. Penyinaran 12 jam (P4) memberikan pertumbuhan terbaik dengan berat mutlak $16,00 \mathrm{~g}$, dan laju pertumbuhan spesifik $4,06 \%$ per hari dan memberikan nilai klorofil- $a$ tertinggi sebesar $2,72 \mathrm{mg} / \mathrm{l}$. Sedangkan nilai fikoeritrin tertinggi terdapat pada (P1) tanpa penyinaran yaitu $4,58 \mathrm{mg} / \mathrm{l}$.

\section{Ucapan Terima Kasih}

Terima kasih penulis ucapkan kepada semua pihak yang telah membantu sehingga terselesaikannya penelitian ini, baik moril maupun materil.

\section{Referensi}

Akib, A., Litaay, M., Asnady, M., Biologi, P. S., Matematika, F., Alam, P., \& Pesisir, J. (2015). Kelayakan Kualitas Air Untuk Kawasan Budidaya Eucheuma Cottoni Berdasarkan Aspek Fisika , Kimia Dan Biologi Di Kabupaten Kepulauan Selayar ( Water Quality Fitness for Cultivation of Eucheuma cottoni based on Physics, Chemitstry and Biology Aspects In Dis. Jurnal Pesisir Dan Laut Tropis, 1(1).

Aulia, S., Ansar, A., \& Putra, G. M. D. (2019). Pengaruh Intensitas Cahaya Lampu Dan Lama Penyinaran Terhadap Pertumbuhan Tanaman Kangkung (Ipomea Reptans Poir) Pada Sistem Hidroponik Indoor. Jurnal Ilmiah Rekayasa Pertanian Dan Biosistem, 7(1), 43-51. https://doi.org/10.29303/jrpb.v7i1.100

Azizah, M. N., Rahman, A., \& Balubi, A. M. (2018). Pengaruh Jarak Tanam Bibit yang Berbeda Terhadap Kandungan Agar Rumput Laut (Gracilaria verrucosa) Menggunakan Metode Longline di Tambak [The Effect of Seed Planting Distances to The Agar Content of Seaweed Gracilaria verrucosa Using Longline Method in Po. Media Akuatika, 3(1), 556563.

Basir, A. P., Abukena, L., \& Alimudin, M. (2017). The Growth Of Seaweed 
(Kappaphycus Alvarezii) Cultivated With Long Line And Off Bottom Method On Tita Banda Neira Maluku Coastal Area. JFMR-Journal of Fisheries and Marine Research, 01(1), 20-23. https://doi.org/10.21776/ub.jfmr.2017.001 .01 .4

Burdames, Y., L.A, E., \& Ngangi. (2014). Kondisi Lingkungan Perairan Budi Daya Rumput Laut di Desa Arakan, Kabupaten Minahasa Selatan. E-Journal Budidaya Perairan, 2(3), 69-75. https://doi.org/10.35800/bdp.2.3.2014.57 06

Cokrowati, N., Diniarti, N., Setyowati, D. N., Waspodo, S., \& Marzuki, M. (2019). Ekplorasi dan Penangkaran Bibit Rumput Laut (Eucheuma cottonii) di Perairan Teluk Ekas Lombok Timur Nunik. Jurnal Biologi Tropis, 19(1), 8-11. https://doi.org/10.29303/jbt.v19i1.994

Cokrowati, N., Lumbessy, S. Y., Diniarti, N., Supiandi, M., \& Bangun, B. (2020). Kandungan Klorofil-A Dan Fikoeritrin Kappaphycus Alvarezii Hasil Kultur Jaringan Dan Dibudidayakan Pada Jarak Tanam Berbeda. Jurnal Biologi Tropis, 20(1), 125-131. https://doi.org/10.29303/jbt.v20i1.1802.

Cokrowati, N., Junaidi, M., Diniarti, N., Scabra, A. R \& Sunaryo. (2021). Introduksi "Bondre" Untuk Mengatasi Gagal Panen Rumput Laut Pada Cuaca Ekstrim di Pantai Jelenga Kabupaten Sumbawa Barat. Jurnal Pengabdian Magister Pendidikan IPA, 4(3). https://doi.org/10.29303/jpmpi.v3i2.946 .

Darmawati. (2013). Analisis Laju Pertumbuhan Rumput Laut Kappaphycus Alvarezii yang Ditanam Pada Berbagai Kedalaman. Octopus. Jurnal Perikanan. Volume 2 No.2.

DOI: https://doi.org/10.26618/octopus.v2i 2.534.

Damayanti, T., Aryawati, R., \& Fauziyah. (2019). Laju Pertumbuhan Rumput Laut
Eucheuma Cottonii ( Kappaphycus Alvarezi ) Dengan Bobot Bibit Awal Berbeda Menggunakan Metode Rakit Apung Dan Long Line Di Perairan Teluk Hurun, Lampung The Growht Rate Of Seaweed Eucheuma cottonii ( Kappahycus alvarezi ) WIT. Maspari Journal, 11(October 2017), 17-22.

Dewi, A. P. W. K., \& Ekawaty, R. (2018). Potensi Budidaya Rumput Laut dalam Kaitannya dengan Dampak Perkembangan Pariwisata di Perairan Pantai Kutuh, Badung, Bali. Journal of Marine and Aquatic Sciences, 5(1), 94. https://doi.org/10.24843/jmas.2019.v05.i0 1.p12

Ega, L., Lopulalan, C. G. C., \& Meiyasa, F. (2016). Kajian Mutu Karaginan Rumput Laut Eucheuma cottonii Berdasarkan Sifat Fisiko-Kimia pada Tingkat Konsentrasi Kalium Hidroksida $(\mathrm{KOH})$ yang Berbeda. Jurnal Aplikasi Teknologi Pangan, 5(2), 38-44.

Giyatmi, Tika, A., Hari, E., Dina, F., Agusman. (2020). Effect of Alginate and Polyethylene Glycol Addition on Physical and Mechanical Characteristics of kCarrageenan-based Edible Film. Squalen. 15(1).

DOI: https://doi.org/10.15578/squalen.v1 $\underline{5 i 1.418}$.

Isa, M. M., Jaelani, L. M., \& Winaro, G. (2016). Analisis Kualitas Air Untuk Budidaya Rumput Laut Eucheuma Cottoni Dengan Citra Landsat. Jurnal Teknik ITS, X(X), 46.

Mahardika, S., Junaidi, M., \& Marzuki, M. (2018). Kandungan Klorofil-A Dan Fikoeritrin Pada Rumput Longline Dengan Kedalaman. E-Journal Budidaya Perairan, 1, 8-13.

Majid, A., Cokrowati, N., \& Diniarti, N. (2016). ( Eucheuma cottonii) Pada Kedalaman Yang Berbeda Di Teluk Ekas , Timur Seaweed Growth Eucheuma Cottonii On Different Depths In Ekas Bay.. E-Journal Budidaya Perairan, 2-5. 
Naseri,A., Charlotte, J., Jimmy,J.P.S., Tommy, E.P., Jan, L., Karin, M.H., MultiExtraction, ... \& Susan, L.H. (2020). Quality of Protein and Carrageenan from Commercial Spinosum (Eucheuma denticulatum). Foods. 9(8).1072; https://doi.org/10.3390/foods9 $\underline{081072 .}$

Parenrengi, A., \& Sulaeman. (2007). Mengenal Rumput Laut, Kappaphycus alvarezii. In Media Akuakultur (Vol. 2, Issue 1, pp. 142-146).

Pusvariauwaty, Notowinarto, R. (2015). Pertumbuhan Morfometrik Thallus Rumput Laut Eucheuma Cottonii Di Perairan Pulau Bulang Batam. Jurnal SIMBIOSA, 4(3), 91-96.

Prastowo, D., Bagus, S., Indah, K., Ari, P. W., Dimas, G. P. (2019). Perbedaan Lama Penyinaran Pada Produksi Plantet Rumput Laut Hasil Kultur Jaringan. Jurnal Perekayasaan Budidaya Air Payau dan Laut. Balai Perikanan Budidaya Air Payau Situbondo. Volume .No. 14. https://kkp.go.id/an.

Runtuboy, N., \& Abadi, S. (2018). Pengaruh Kedalaman terhadap Perkembangan Rumput Laut Kotoni Hasil Kultur Jaringan. Jurnal Penyuluhan Perikanan Dan Kelautan, 12(3), 203-213. https://doi.org/10.33378/jppik.v12i3.110.

Rukisah, Burhanuddin, I., \& Aswar, G. (2020). Penagruh Kedalaman Terhadap Pertumbuhan dan Produksi Warna Rumput Laut (Kappaphycus alvarezii) di Perairan Pantai Amal Kota Tarakan. Jurnal Agroqua. 18(1). 10.32663/ja.v\%vi\%i.1148.

Subagio, \& Kasim, M. S. H. (2019). No Identifikasi Rumput Laut (Seaweed) di Perairan Pantai Cemara, Jerowaru Lombok Timur Sebagai Bahan Informasi Keanekaragaman Hayati Bagi Masyarakat Subagio. Jurnal JISIP, 3(2), 308-321. http://repositorio.unan.edu.ni/2986/1/562 4.pdf.
Yulius, M. R. (2017). Pengelola Budidaya Rumput Laut Berbasis Daya Dukung ( Seaweed Aquaculture Management Base on Environmental Waters Carrying Capacity in. Peneglola Budidaya Rumput Laut Berbasis Daya Dukung Lingkungan, $1-10$. 